Impact assessment on the tourism community extension project to the beneficiary of SHL restoration village

\author{
Borbon, Noelah Mae D. $\triangle$ \\ Lyceum of the Philippines University - Batangas, Philippines (nmdborbon@lpubatangas.edu.ph) \\ Ylagan, Alex D. \\ Lyceum of the Philippines University - Batangas, Philippines (apylagan@lpubatangas.edu.ph)
}

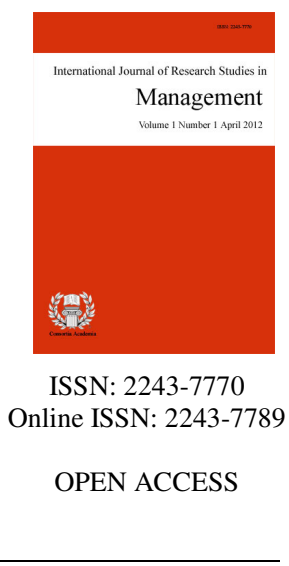

Received: 5 December 2020

\title{
Abstract
}

Community Extension is one of the tri-fold functions in Lyceum of the Philippines University Batangas thus plays an important role in the social transformation and became an instrument in changing lives of many Batanguenos by providing sustainable projects. The College of International Tourism and Hospitality Management conducts this livelihood project through their faculty member and students teaching the residents on beads making and selling these bracelets. This study assessed impact and effectiveness of the livelihood project to the Beneficiary of SHL Restoration Village. The participants of the study will be those residents of SHL Restoration Village covering 50 houses. There is a total of 20 beneficiaries who voluntarily serve to be part of livelihood project which is the beads making. The instrument that will be used in this study is a self-made questionnaire to assess the impact of the livelihood project in terms of values gained and economic status and the effectiveness of the project. Based on the result of the study, it was revealed that there was a positive impact on the beneficiaries, CITHM Faculty and students. It is also proven that the livelihood project is effective. Furthermore, it is revealed that the impact of the project is not affected on whether the project is effective. It is suggested that livelihood project and program may be continued since there is a positive impact to the benefactors; however, it is recommendable to fine other beneficiaries and may look for industry partners to have regular customers to ensure sustainability of the project.

Keywords: community extension; entrepreneurial; effectiveness; volunteerism 


\section{Impact assessment on the tourism community extension project to the beneficiary of SHL restoration village}

\section{Introduction}

Impact assessment is the process of identifying the anticipated or actual impacts of a development intervention, on social, economic and environmental factors (Roy, 2016). The use of impact assessment can be characterized on a scale with 'proving impact' on one side and 'improving practices' on the other (Rijn et al., 2012). It is essential for the organization to evaluate and assess the project that has commenced for continuous improvement.

Tourism's role in achieving the 17 Sustainable Development Goals (SDGs) can be significantly strengthened when sustainable development becomes a shared responsibility and moves to the core of decision-making within the tourism sector. A joint effort by UNWTO, UNDP and other partners, Tourism and the Sustainable Development Goals - Journey to 2030 aims to build knowledge and empower and inspire tourism stakeholders to take necessary action to accelerate the shift towards a more sustainable tourism sector by aligning policies, business operations and investments with the Sustainable Development Goals (Tourism and the Sustainable Development Goals - Journey to 2030, 2018).

Community Extension is one of the tri-fold functions in Lyceum of the Philippines University Batangas thus plays an important role in the social transformation and became an instrument in changing lives of many Batanguenos by providing sustainable projects. One of the sustainable community extensions of the university is the Livelihood project among the residents of SHL Restoration Village, these residents were adopted by the university giving them a place to stay and allowing them join different community extension project to sustain and improve their quality of life.

The College of International Tourism and Hospitality Management conducts this livelihood project through their faculty member and students teaching the residents on beads making and selling these bracelets. The main objective of this project is to support for them economically and help their community. It is focused on providing opportunities to increase their income generating capacity. The college provides materials for the products with less expensive source of working capital to create their own income. The college also provides them the tools needed and they are working for every bracelet that they make.

Livelihood project is such a good approach that will have a good result and improved economic opportunities for many. This study would like to evaluate the effectiveness of the livelihood project spearheaded by the college. The findings of the study would benefit not only the college but more so the adopted community and families in SHL Restoration Village in the long run for having action plan for continuous improvement.

\subsection{Community extension program}

Community resilience is effective in conducting community needs assessment. It helps in developing a healthy family life in the community environment and reduces social incidents (Pfefferbaum et al., 2013). Moreover, to conduct a community need assessment, feedback from the local resident is very much needed as to getting their feedback and experiences towards the surrounding. According to Krumwiede et al. (2015) those students participating to the service learning project or the community extension program took advantage by inculcating their knowledge from the classroom discussion and put it into action through the projects and program. The community extension is good on both parties, towards the community and to the students participating. With the use of proper planning and preparation, there would be a successful sustainable community extension that will have a great long-term impact to the society and will be passed from generations 
to generations.

In the recent study in the Academic Hospital Partnership shows that most of the students are developing various skills and competence as they can participate in the service learning project. These projects were geared towards the life skills, career development and creating impact to other's life through collaboration (Krumwiede et al., 2015). Furthermore, it is essential in community extension program to measure the effectively by evaluating its impact not only to the impact to the community but more importantly looking consideration to the impact created towards the student. According to Pfefferbaum et al. (2013) the importance of conducting community assessment are creating self- awareness and assuring community participation and cooperation and thus there is a possibility to maximize the resource to produce purposive response towards the need of the community. However, this may not be easily being seen in some community due to culture differences thus it is an advantage to conduct needs assessment to assess the scope and limitation of the community. This will enable to create more sustainable long-term project since it would be need based. Furthermore, Lewis (2018) believes that the most important assets when it comes to community extension are the following: emerging technologies in agriculture; opportunities in urban agriculture; existing facilities and resources; and actively engaged and collaborative citizens.

\subsection{Sustainable livelihood project}

A "livelihood" is defined as one's "means of support or subsistence" or the activities that economically support a person and his/her family. It is focused on providing opportunities for the working poor (in various occupations) to increase their income-generating capacity. According to Mollel (2018), some community has low income due to the poor infrastructure for conducting their main economic activity which is beads products making and selling. For this case the prioritized project was construction of beads products shop which will increase sells, improve their income and hence improve livelihood. On the other hand, the findings Agyemang et al. (2019) revealed that the socialization process of the knowledge creation model was intensively practiced in the beads-making communities to create and utilize knowledge, while the internalization, combination and externalization processes were practiced at a low rate. Dua et al. (2019), defined entrepreneur as a person responsible for setting up a business or an enterprise. He has the initiative, skill for innovation and who looks for high achievements. In the livelihood project conducted, one of the objectives is to mold the beneficiaries to be entrepreneur even in small capital growing into bigger capital. Also, in another study represented a limited sample of 24 African women from an impoverished community and does not represent other population groups in contemporary South Africa. This clearly warrants further quantitative and qualitative research to be conducted with a mixed-race profile to explore the experiences of women involved in economic development cooperative projects across various provinces in South Africa. Furthermore, it is essential to monitor projects closely to ensure transparency and accountability by project managers of economic development cooperative projects (Raniga, 2018).

\subsection{Objective of the study}

This study assessed impact and effectiveness of the livelihood project to the Beneficiaries of SHL Restoration Village. More specifically, it aimed to evaluate the effectiveness of the livelihood project to the Beneficiaries of SHL Restoration Village; to assess the impact of the livelihood project in terms of values gained and economic status. Moreover, the study determines the significant relationship on the impact and effectiveness of the livelihood project. As an output, the researcher proposed a recommendation for continuous improvement.

\section{Research methods}

This study used a descriptive method to assess the impact of the livelihood project to the Beneficiary of SHL Restoration Village as a basis for the proposal for sustainable tourism community extension program. The participants of the study are the residents of SHL Restoration Village covering 50 houses. There are a total of 20 
beneficiaries who voluntarily served to be participated in the livelihood project which the beads is making project. The instrument that used in this study is an adopted questionnaire from Borbon (2019) to assess the impact of the livelihood project in terms of values gained and economic status. The researcher conducted the distribution of questionnaires to the residents of SHL Restoration Village through online survey form. The collected data were tallied, encoded and interpreted using different statistical tools such as weighted mean, Rank and Analysis of Variance (ANOVA).

\section{Result and discussion}

\section{Table 1}

Impact of the livelihood project as to values

\begin{tabular}{lccc}
\hline \multicolumn{1}{c}{ Indicators } & WM & Verbal Interpretation & Rank \\
\hline Improved my quality of life & 3.74 & Very Much & 1 \\
Build up my confidence & 3.50 & Very Much & 4.5 \\
Develop my creativity & 3.50 & Very Much & 4.5 \\
I become responsible citizen & 3.70 & Very Much & 2 \\
Give me chance to be productive & 3.62 & Very Much & 3 \\
\multicolumn{1}{c}{ Composite Mean } & 3.61 & Very Much & \\
\hline Legend: $350-4.00=$ Very
\end{tabular}

Legend: $3.50-4.00=$ Very Much; $2.50-3.49=$ Much; $1.50-2.49=$ Little; $1.00-1.49=$ Not at All.

Table 1 displays the impact of livelihood project as to values. The composite mean of 3.61 implies that there was a positive impact. Among the items cited, improvement the quality of life got the highest weighted mean score of 3.74. One of the objectives stated in the project proposal is to create better life to beneficiaries by empowering the adopted families of SHL restoration Village by providing them with substantial source of living through a livelihood program. Volunteering yourself has been proven that giving time, effort or material goods to others contributes to happiness. It will help not only for the beneficiaries but more so for the faculty and students to make new friends and increase the social and relationship skills with others. Someone having a stronger desire to help an individual through their work enjoy higher life-satisfaction. Thus, creating a positive impact to everyone.

Community resilience is effective in conducting community needs assessment. It helps in developing a healthy family life in the community environment and reduces social incidents (Pfefferbaum et al., 2013). Moreover, to conduct a community need assessment, feedback from the local resident is very much need as to getting their feedback and experiences towards the surrounding. Since before the project was implemented, it undergone into needs assessment and so the project created a positive impact as it was planned effectively.

It was followed by become responsible citizen (3.70) and give them chance to be productive (3.62). The Community Extension Program molds the student, faculty members and the beneficiaries to become responsive members of the society, to enhance college community extension program and services. Through these programs they can feel the essence of our existence to help the people in our own ways. They provide opportunities to the community this Livelihood Program is an activity of extending a hand to the people. They interact with residents and gave some additional learnings in life that they can use in their livelihood like making bracelets. This program is a support for them economically and to develop individuals into becoming responsible citizens for the transformation of the society. According to Krumwiede et al. (2015) those students participating to the service learning project or the community extension program took advantage by inculcating their knowledge from the classroom discussion and put it into action through the projects and program.

The community extension is good on both parties, towards the community and to the students participating. With the use of proper planning and preparation, there would be a successful sustainable community extension that will have a great long-term impact to the society and will be passed from generations to generations. However, build up their confidence (3.50) and develop my creativity (3.50) both obtained the same rank and rated the least. The university being a storage, generator and disseminator of knowledge, should make an impact 
Impact assessment on the tourism community extension project to the beneficiary of SHL restoration village

on the community within its reach. Although its graduates will naturally be involved in the development of the community where they work and live, there are a lot more people who were not able to have formal university training, and need outside help to make them productive members of the community.

Unfortunately, not everyone was able to participate due to some schedule conflict and some were not that interested. Nonetheless, for those interested residents through the project they were able to come up with good bracelet however the concern is that it lacks creativity and confidence to the extent that the tourism students need to repeat the process due to the color combination among the bracelet was not that good and pleasing to the eyes. Projects were geared towards the life skills, career development and creating impact to other's life through collaboration (Krumwiede et al., 2015). Furthermore, it is essential in community extension program to measure the effectively by evaluating its impact not only to the impact to the community but more importantly looking consideration to the impact created towards the student and the beneficiaries 21 st century skills which includes confidence, resourcefulness and creativity.

\section{Table 2}

Impact of the livelihood project as to economic status

\begin{tabular}{llcc}
\hline \multicolumn{1}{c}{ Indicators } & WM & Verbal Interpretation & Rank \\
\hline Help provide needs of my family & 3.60 & Very Much & 5 \\
Help me have a regular source of income & 3.62 & Very Much & 3.5 \\
Give me opportunity to save for the future & 3.62 & Very Much & 3.5 \\
Able to handle my finances very well & 3.78 & Very Much & 1 \\
Inspire me to put my own small business & 3.66 & Very Much & 2 \\
Composite Mean & 3.66 & Very Much & \\
\hline Legend: $3.50-4.00=$ Very Much; $2.50-3.49=$ Much; $1.50-2.49=$ Little; $1.00-1.49=$ Not at All.
\end{tabular}

Table 2 displays the impact of livelihood project as to economic status. The composite mean of 3.66 implies that there was a positive impact. Among the items cited, ability to handle the finances very well got the highest weighted mean score of 3.78. It was followed by having an inspiration to put also their own small business with the weighted mean of 3.66. One of the objective stated in the project proposal is that this livelihood program enables the beneficiaries to start up a small- scale home income generating souvenir. Bracelet making is an interesting hobby at the same time; they will earn their income from that. The purpose of the said activity is to widen the knowledge of the individuals especially the mothers to have their business at home while earning. Moreover, according to Dua et al. (2019), entrepreneur is someone that is responsible for setting up a business or an enterprise. He has the initiative, skill for innovation and who looks for high achievements. In the livelihood project conducted, one of the objectives is to mold the beneficiaries to be entrepreneur even in small capital growing into bigger capital.

However, help the beneficiaries to have a regular source of income (3.62) and Give them an opportunity to save for the future (3.62) both obtained the same rank and ability to help providing the needs of their family rated the least with the weighted mean of 3.60. This Livelihood Program is a support for the beneficiaries to help them economically help their community. It is focuses on providing opportunities to increase their income generating capacity. Though this is of good purpose and opportunity, still to make a regular source of income and to be able to save for the future and provide for the needs of the family it demands hard work and consistency on the output. But due to some constraints, it wasn't able to provide a large amount since the money that they were able to collect is just a portion and percentage from the total output that made. Furthermore, it is essential to monitor projects closely to ensure transparency and accountability by project managers of economic development cooperative projects (Raniga, 2018).

Table 3 displays the effectiveness of livelihood project. The composite mean of 3.38 implies that the livelihood project is effective. Among the items cited, the project is successful and effective got the highest weighted mean score of 3.56. It was followed by the Faculty and students teaches the beneficiaries effectively (3.38) and there is enough time allotted in the project to make it successful (3.36). One of the objective stated in 
Borbon, N. M. D., \& Ylagan, A. D.

the project proposal is to encourage CITHM faculty, staff and students to involve themselves in this livelihood community extension program of the college by developing social concern and establish spirit of volunteerism from among the students and faculty members of the university and to monitor sustainability of the project initiated by CITHM to the adopted community. This will enable to create more sustainable long-term project since it would be need based. Furthermore, Lewis (2018) believes that the most important assets when it comes to community extension are the following: emerging technologies in agriculture; opportunities in urban agriculture; existing facilities and resources; and actively engaged and collaborative citizens.

Table 3

Effectiveness of the livelihood project

\begin{tabular}{lccc}
\hline \multicolumn{1}{c}{ Indicators } & WM & Verbal Interpretation & Rank \\
\hline The Faculty and students teach the beneficiaries effectively & 3.38 & Effective & 2 \\
There is enough time allotted in the project to make it successful & 3.36 & Effective & 3 \\
The project is well funded and supported by the college and LPU & 3.34 & Effective & 4 \\
The project also helps the save and preserve the environment & 3.28 & Effective & 5 \\
The project is successful and effective & 3.56 & Highly Effective & 1 \\
& Composite Mean & 3.38 & Effective \\
\hline
\end{tabular}

Legend: $3.50-4.00$ = Highly Effective; 2.50 - 3.49 = Effective; 1.50 - 2.49 = Less Effective; 1.00 - 1.49 = Not Effective.

However, The project is well funded and supported by the college and LPU followed in the ranking with the weighted mean of 3.34. The project also help the save and preserve the environment obtained the weighted mean of 3.28 and rated the least. The CITHM Faculty and students work hand in hand to provide materials for the products with less expensive source of working capital to create their own income. By making these bracelets the students will collect the bracelet that was created by the residents and helped in the the costing on how much each bracelet they made will be sold, together, the residents with the help of the CITHM students and faculty promote, market and were able to sell the products. When all the product are sold, a portion of the profit goes to the residents and a portion of that is allotted for buying and giving the materials to beneficiaries to ensure that it will continuously flow. To make this happen all of them should work together. Providing them the tools needed and they are working for every bracelet that they make. This is such a good approach that will have a good result and improved economic opportunities for many. However, it somehow reflects on spoon feeding on the beneficiaries. So as much as possible, it is better to let them do the work after teaching them on how to create the finish product. According to Mollel (2018), some community have low income due to the poor infrastructure for conducting their main economic activity which is beads products making and selling. For this case the prioritized project was construction of beads products shop which will increase sells, improve their income and hence improve livelihood.

\section{Table 4}

Relationship between the impact of the livelihood project and its effectiveness

\begin{tabular}{lccc}
\hline \multicolumn{1}{c}{ Impact } & $r$-value & $p$-value & Interpretation \\
\hline Values & $0.135^{* *}$ & 0.352 & Not Significant \\
Economic Status & $0.136^{* *}$ & 0.347 & Not Significant \\
\hline Legend Significant at $p$-value $<01$ & & &
\end{tabular}

Legend: Significant at $p$-value $<.01$

Table 4 presents the association between the impact and the effectiveness of the livelihood project. The resulted $r$-values indicates a weak coorrelation and the compputed $p$-values were greater than .01 alpha level which implies that there was no significant relationship between the two variables. This means that the impact of the project is not affected on whether the project is effective. The Livelihood program consists of making of souvenir items available for sale. Souvenir items such as keychain, picture frames, plant holders and other home decors from recycled materials. Accessories such as bracelets, necklace and another accessory that are personalized. This souvenir items and accessories will be hand made by the adopted families of SICO and will be available for sale. The CITHM faculty and students will be helping the family in making and selling of the said items and products. A "livelihood" is defined as one's "means of support or subsistence" or the activities 
Impact assessment on the tourism community extension project to the beneficiary of SHL restoration village

that economically support a person and his/her family. It is focused on providing opportunities for the working poor (in various occupations) to increase their income-generating capacity. Furthermore, the findings Agyemang et al. (2019), revealed that the socialization process of the knowledge creation model was intensively practiced in the beads-making communities to create and utilize knowledge, while the internalization, combination and externalization processes were practiced at a low rate.

\section{Conclusion and recommendation}

There is a positive impact of the project in terms of values gained is that the beneficiaries were able to have an improved quality of life and for economic status, the beneficiaries were able to manage their finances very well. Also, it is revealed that the livelihood project was effective. Moreover, the study proves that there is no significant relationship on the impact and effectiveness of the livelihood project. The College of International Tourism and Hospitality Management to may continue the livelihood project and program since there is a positive impact to the benefactors, however, it is recommendable to find other beneficiaries. The future faculty trainer may provide avenue for the beneficiaries to be entrepreneurial ready focusing on the 21st century skills: confidence, resourcefulness and creativity. The College may look for more industry partners may it be local or international partners to have regular customers and ensure sustainability of the project. Future researchers may continue to explore on the impact assessment of other beneficiaries having different set of variables.

\section{References}

Agyemang, B. K., Ngulube, P., \& Dube, L. (2019). Utilising knowledge management methods to manage beads-making indigenous knowledge among the Krobo communities in Ghana. South African Journal of Information Management, 21(1), 1-9. https://doi.org/10.4102/sajim.v21i1.1008

Borbon, N. M. D. (2020). Impact assessment on the beneficiaries of the Sanayang Kabuhayang Industriyal Program. Asia Pacific Journal of Multidisciplinary Research, 8(2), 77-85.

Dua, K., Dilbaghi, M., \& Gandhi, S. (2019). Gender participation and work station analysis of bead making enterprises. Journal of Pharmacognosy and Phytochemistry, 8(1), 1477-1480.

Krumwiede, K. A., Van Gelderen, S. A., \& Krumwiede, N. K. (2015). Academic-hospital partnership: Conducting a community health needs assessment as a service learning project. Public Health Nursing, 32(4), 359-367. https://doi.org/10.1111/phn.12159

Lewis, D. (2018, April). A paradigm in assessing community needs. In S. Windon and A. Elhadi (Eds.), Proceedings of the 34th Annual Conference of AIAEE: Celebrating the Intersection of Human, Natural, and Cultural Systems (p. 13). Merida, Yucatan, Mexico.

Mollel, P. J. (2018). Improving livelihood of Nguzo Nyarugusu refugee women group by constructing beads products shop in Nyarugusu, Kasulu District, Kigoma [Doctoral dissertation, The Open University of Tanzania].

Pfefferbaum, R. L., Pfefferbaum, B., Van Horn, R. L., Klomp, R. W., Norris, F. H., \& Reissman, D. B. (2013). The communities advancing resilience toolkit (CART): An intervention to build community resilience to disasters. Journal of public health management and practice, 19(3), 250-258. https://doi.org/10.1097/PHH.0b013e318268aed8

Raniga, T. (2018). Poverty alleviation, social protection policy and sustainability of economic development cooperatives: Voices of women residing in Bhambayi, KwaZulu-Natal, South Africa. Social Work, 54(4), 395-406. https://doi.org/10.15270/54-4-668

Rijn, F., Burger, K., \& Belder, E. (2012). Impact assessment in the sustainable livelihood framework. Development in Practice, 22(7), 1019-1035. https://doi.org/10.1080/09614524.2012.696586

Roy, A. K. (2016). Impact assessment of an intervention' improved pig farming technology' for livelihood improvement of rural poor at Dhalai District, Tripura. International Journal of Bio-resource, Environment, and Agricultural Sciences. 
Borbon, N. M. D., \& Ylagan, A. D. 